\title{
Potensi perasan Daun Binahong (Anredera cordifolia) sebagai antibakterial pada kultur media bakteri Staphylococcus aureus dan Esherichia coli penyebab mastitis klinis penyebab mastitis Sapi Perah
}

\author{
Pratiwi Trisunuwati dan Endang Setyowati \\ Dosen Fakultas Peternakan Universitas Brawijaya
}

Correspondence author : pratiwi_trisunuwati@yahoo.com

\begin{abstract}
This research was conducted to determine the ability of binahong (Anredera cordifolia (Ten.) Steenis) leaf juice as alternative herbal antibacterial against teat dipping mastitis of livestock. Pure isolate of Staphylococcus aureus and Esherichia coli taken from sub clinical mastitis of dairy cow were used in this experiment. The experiment was examined with four different treatments and five replication $60 \%\left(\mathrm{P}_{1}\right), 80 \%\left(\mathrm{P}_{2}\right)$, and $100 \%\left(\mathrm{P}_{3}\right)$ of binahong leaf juice concentration's as treatment and iodips 10\% (P0) as placebo. Based on statisctical method, the result prove that binahong's leaf juice had potentially reduced against growth of bacteria as play of inhibition's zone on NA media culture. Mostly $100 \%\left(\mathrm{P}_{3}\right)$ of binahong leaf juice concentrations was the best treatment that gave inhibition zone in Staphylococcus aureus $(9.72 \pm 4.36 \mathrm{~mm})$ and Escherichia coli $(9.15 \pm 4.57 \mathrm{~mm})$. This could be concluded that binahong's leaf juice had an ability avoid growth of mastitis bacteria and it can be potentially used as herbal antibacterial in teat dipping to against mastitis.
\end{abstract}

Keywords: Binahong leaf juice, herbal antibacterial, inhibition zone

\section{PENDAHULUAN}

Susu merupakan salah satu produk yang dihasilkan oleh sapi perah dan salah satu bahan pangan yang sangat penting bagi pemenuhan kebutuhan gizi masyarakat. Namun, fakta menunjukkan bahwa konsumsi susu nasional sampai saat ini belum dapat dipenuhi melalui produksi dalam negeri. Data Badan Pusat Statistik produksi susu nasional pada tahun 2015 hanya 805.363 ton dimana pada tahun 2009 produksi susu mencapai 827.249 ton. Penyebab utama penurunan produksi karena kesalahan manajemen pemerahan adalah mastitis (Abrar dkk., 2013).

Bakteri penyebab mastitis subklinis terbanyak berturut-turut antara lain Streptococcus agalactiae, Staphylococcus aureus, Staphylococcus epidermidis, dan Escherichia coli (Poeloengan, 2009).

Pada kondisi lapang pencegahan yang umumnya dilakukan para peternak untuk mencegah jangkitan penyakit mastitis adalah melalui pencelupan puting setelah pemerahan menggunakan desinfektan bahan kimia. Namun, banyak permasalahan muncul dari digunakannya desinfektan berbahan kimia tersebut. Penggunaan desinfektan kimia terbukti memiliki banyak kelemahan seperti yang disebutkan oleh Setiawan dkk. (2007) yaitu dapat menimbulkan resistensi dan residu kimia. Selain itu banyak peternak yang 
mengeluhkan tingginya biaya untuk pembelian desinfektan tertentu (Sugiri dan Anri, 2010).

Alternatif yang dapat digunakan sebagai bahan pencelupan puting adalah bahan alami daritumbuhan sebagai phytoherbal. Sebagai alternatif tumbuhan adalah daun binahong (Anredera cordifolia) yang mempunyai komposisi senyawa flavonoid, alkaloid, terpenoid atau steroid, dan saponin (Astuti, 2012). Demikian pula dilaporkan pada peneliti terdahulu mengandung polifenol, serta memiliki aktivitas antibakteri terhadap Staphylococcus aureus dan Escherichia coli (Desriani dkk., 2014). Tanaman binahong juga dapat ditanam sendiri dengan perawatan yang mudah dan hampir dapat dijumpai dimanapun, hal ini tentunya memberikan nilai ekonomis untuk digunakan sebagai desinfektan alami.

Berdasarkan kandungan daun binahong yang bermanfaaat tersebut, maka perasan daun binahong berpotensi dan layak dimanfaatkan sebagai antimikroba patogen. Ditunjang dengan hasil penelitian Darsana dkk. (2012) bahwa remasan $100 \%$ daun binahong dapat meningkatkan daya hambat pertumbuhan E.coli secara in vitro, linier dengan peningkatan konsentrasi perasan daun binahong meningkatkan daya hambat terhadap pertumbuhan bakteri Escherichia coli.

Berdasarkan uraian tersebut, perasan daun binahong (Anredera cordifolia) diharapkan dapat menghambat pertumbuhan bakteri Staphylococcus aureus dan Esherichia coli yang diisolasi dari kasus mastitis klinis pada sapi perah, sehingga akan menurunkan angka kejadian mastitis pada peternak skala kecil.

\section{MATERI DAN METODE}

Sampel bakteri diisolasi dari air susu mastitis klinis sapi perah berupa Staphylococcus aureus dan Esherichia coli. Daun binahong (Anredera cordifolia) diperoleh dari daerah Tulusrejo, Kabupaten Malang. Sebagai pengencer perasan digunakan aquabidest. Pelaksanaan pengujian dilakukan di Lab. HPT Fakultas Pertanian UB.

Alat yang digunakan antara lain timbangan analitik, mortar, kain saringan, erleme yer autoklaf, tabung reaksi, cawan petri, erlenmeyer, bunsen, gelas ukur, mikro pipet, jangka sorong, stirrer, cork borer, kertas label, pengaduk, tisu, pinset, dan plastic wrap. Bahan yang digunakan adalah perasan daun binahong dan aquades. Bahan yang digunakan dalam uji daya hambat adalah larutan iodips 10\%, bakteri Staphylococcus aureus, bakteri Esherichia coli, media nutrient agar (NA), alkohol 70\%, dan aquadest steril.

Metode experimental murni dengan RAL dengan empat perlakuan (P0, P1, P2, P3) dan 5 ulangan. Uji daya hambat anti bakteri perasan daun binahong (Anredera cordifolia) terhadap bakteri Staphylococcus aureus dan Esherichia coli menggunakan metode sumuran.

Dilaksanakan bulan Juni sampai Juli 2016 di Lab. HPT Fakultas Pertanian UB.

\section{Tahapan Penelitian}

\section{Proses untuk memperoleh perasan daun binahong}

Daun dewasa binahong diambil tiga perempat dari pangkal batang tanaman binahong sebanyak 500 gr, dicuci bersih lalu ditiriskan kemudian 
dihaluskan dengan cara ditumbuk menggunakan lumpang dan alu. Daun dewasa dapat dilihat berdasarkan warna daun yaitu tidak terlalu berwarna hijau muda ataupun hijau tua. Trikoma sebagai tempat akumulasi bioaktif lebih banyak terdapat pada daun dewasa atau tiga perempat dari pohon. Daun binahong yang sudah dihaluskan kemudian diperas menggunakan tangan dengan bantuan kain saring bersih hingga menghasilkan perasan daun binahong dengan konsentrasi $100 \%$.

\section{Pembuatan konsentrasi perasan daun binahong}

Perasan daun binahong masingmasing diuji daya hambat dengan konsentrasi P1 (60\%), P2 (80\%), P3 $(100 \%)$, dengan rincian sebagai berikut:

- P1 $(60 \%)=6 \mathrm{ml}$ perasan kental daun binahong $+4 \mathrm{ml}$ aquades

- $\mathrm{P} 2(80 \%)=8 \mathrm{ml}$ perasan kental daun binahong $+2 \mathrm{ml}$ aquades

- P3 $(100 \%)=10 \mathrm{ml}$ perasan kental daun binahong tanpa diencerkan dengan aquades

\section{Pembuatan media nutrient agar (NA)}

Medium Nutrient Agar (NA) dengan spatula atau sendok yang telah disediakan dan timbanglah seberat 2,5 gr, tambahkan pada $250 \mathrm{ml}$ aquabidest, kemudian dipanaskan pada suhu $121^{\circ} \mathrm{C}$ selama 15 menit. (Prawira dkk., 2013).

\section{Kultur bakteri}

Inokulasi bakteri pada cawan petri yang berisi media NA (Kusuma dkk. 2014)

1. Isolat bakteri diambil sebanyak $1 \mathrm{ml} \mathrm{CFU} 10^{8}$

2. Diinokulasikan bakteri dengan metode gores zigzag pada media padat
3. Diinkubasi selama 24 jam pada suhu $37^{0} \mathrm{C}$ pada incubator

4. Diambil 2 ose bakteri yang sudah diremajakan untuk dipanen dan dimasukkan ke dalam aquades steril $100 \mathrm{ml}$.

\section{Uji daya hambat}

Proses uji daya hambat menurut

Darsono dan Artemisia (2003) menggunakan metode sumuran adalah sebagai berikut:

1. Biakan bakteri aktif sebanyak 100 $\mu \ell$ (Staphylococcus aureus $8,1 \times 10^{7}$; Escherichia coli $9,4 \times 10^{7}$ $\mathrm{CFU} / \mathrm{ml}$ ) diambil menggunakan mikropipet, dimasukkan kedalam cawan petri yang telah berisi media padat. Suspensi bakteri diinokulasikan dengan cara diratakan menggunakan spreader.

2. Media yang telah bercampur dengan bakteri dilubangi dengan cork borer, diameter lubang 5 $\mathrm{mm}$.

3. Pada setiap sumuran dimasukkan perasan daun binahong ( $\mathrm{P} 1, \mathrm{P} 2$, P3) serta placebo (P0) dengan iodips dan dengan mikropipet.

4. Kultur dalam cawan ditutup menjaga kontaminasi kemudian diinkubasi selama 24 jam dalam incubator.

5. Pengamatan berikutnya adalah mengukur diameter radial zona bening di sekitar sumuran.

\section{Pengukuran diameter zona bening}

Adanya zona bening di sekitar daerah sumuran merupakan area yang tidak terdapat pertumbuhan bakteri. Perhitungan besarnya zona hambat menurut Zahara dkk. (2013) adalah sebagai berikut:

$\underline{(\mathrm{d} 1+\mathrm{d} 2}-\mathrm{X}$ 
2

Keterangan:

- $\mathrm{d} 1$ = diameter vertikal zona bening yang terbentuk

- $\mathrm{d} 2=$ diameter horizontal zona bening yang terbentuk

- $\mathrm{X}=$ lubang sumuran (5 mm)

Tabel 1. Kategori zona hambat

\begin{tabular}{cc}
\hline $\begin{array}{c}\text { Diameter } \\
(\mathrm{mm})\end{array}$ & $\begin{array}{c}\text { Respon Hambatan } \\
\text { Pertumbuhan }\end{array}$ \\
\hline $0-3 \mathrm{~mm}$ & Lemah \\
$3-6 \mathrm{~mm}$ & Sedang \\
$>6 \mathrm{~mm}$ & Kuat \\
\hline
\end{tabular}

(Pan et al, 2009)

\section{Variabel Penelitian}

a. Variabel independent Variabel independent bebas dalam penelitian ini adalah perasan daun tanaman binahong dengan aquabides dengan konsentrasi, $\mathrm{P}_{1}$ (60\%), $\mathrm{P}_{2}$ (80\%), $\mathrm{P}_{3}$ (100\%), dan iodips $10 \%\left(\mathrm{P}_{0}\right)$.

b. Variabel dependent

Variabel dependent adalah diameter zona hambat berupa daerah bening yang terbentuk yang menunjukkan tidak terdapat pertumbuhan bakteri Staphylococcus aureus dan Escherichia coli kemudian membandingkan besarnya efektivitas kofisentęalsi perasan daun binahong terhadap daya hambat tumbuhnya bakteri. $\quad 3,67 \pm 1,52^{\mathrm{a}}$

\section{Analisis Data}

Penelitian ini menggunakan 4 perlakuan dan 5 ulangan. Data yang diperoleh dianalisis menggunakan Anova yang dilanjutkan dengan MDRS.

Gambar 1. Grafik zona hambat Staphylococcus aureus

\section{HASIL DAN PEMBAHASAN}

\section{Analisis uji hambat Staphylococcus aureus}

Dari Tabel 2 terlihat bahwa konsentarasi $100 \%$ perasan memberikan akibat terhadap hambatan peling besar antar perlakuan $(\mathrm{P}<0,01)$ yang melebihi placebo dengan iodip $10 \%$.

Tabel 2. Analisis zona hambat bakteri

\begin{tabular}{lcl}
\multicolumn{3}{c}{ Staphylococcus aureus } \\
\hline Perlakuan & $\begin{array}{c}\text { Diameter } \\
\text { Zona } \\
\text { Hambat } \\
(\mathrm{mm})\end{array}$ & $\begin{array}{c}\text { Kategori } \\
\text { Respon }\end{array}$ \\
\hline P0 (iodip) & $6,82 \pm 2,91^{\mathrm{b}}$ & Kuat \\
P1 (60\%) & $3,67 \pm 1,52^{\mathrm{a}}$ & Sedang \\
P2 (80\%) & $4,47 \pm 1,94^{\mathrm{a}}$ & Sedang \\
P3 (100\%) & $9,72 \pm 4,36^{\mathrm{c}}$ & Kuat \\
\hline
\end{tabular}

Keterangan: superskrip menunjukkan perbedaan antar perlakuan.

Rataan diameter zona hambat perasan daun binahong pada setiap perlakuan memiliki perbedaan yang sangat nyata $(\mathrm{P}<0,01) \quad$ terhadap pertumbuhan bakteri Staphylococcus aureus. Berdasarkan hasil uji dapat

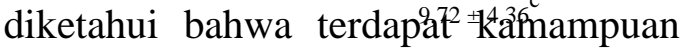
antibekteri seiring dengan peningkatan konsentrasi remasan daun binahong.

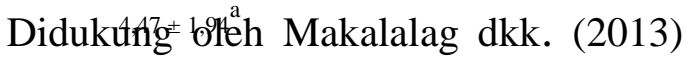
bahwa banyaknya zat aktif yang terkandung dalam perasan daun binahong dipengaruhi oleh banyaknya pelarut atau pengencer yang digunakan. Semakin banyak pelarut yang digunakan maka semakin sedikit zat aktif yang terkandung. 


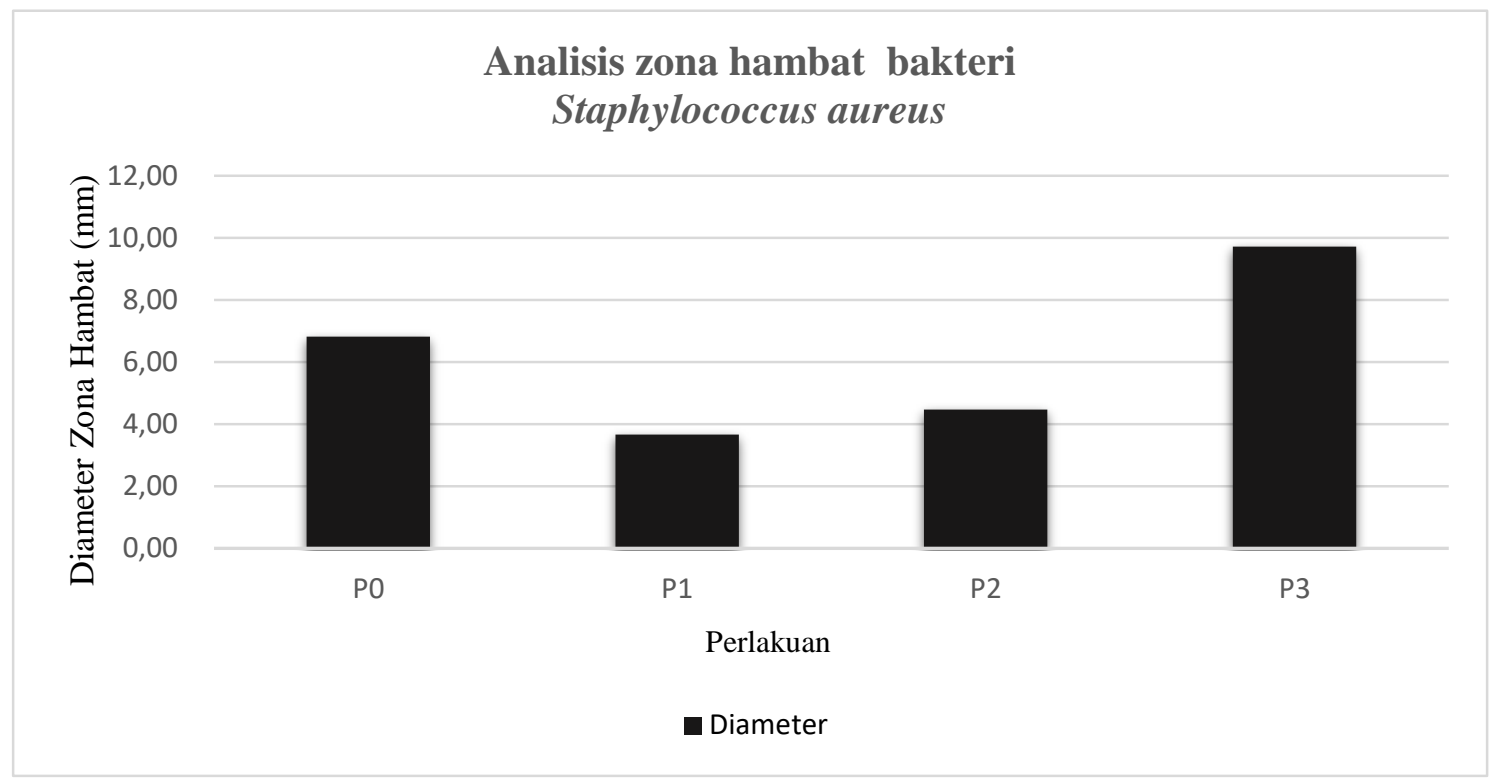

Diameter rata-rata zona hambat perasan daun binahong pada setiap perlakuan memiliki perbedaan yang sangat nyata $(\mathrm{P}<0,01) \quad$ terhadap pertumbuhan bakteri Staphylococcus aureus. sehingga perlu sehingga perlu dilakukan uji lanjutan menggunakan uji jarak berganda duncan. Tabel 3 menunjukkan bahwa perasan daun binahong pada konsentrasi $100 \%$ (P3) memiliki daya hambat lebih kuat pada E. coli dibandingkan iodip $10 \%$ (P0) Konsentrasi 60\% (P1) dan P2 80\% (P2) diketahui belum dapat mengungguli besarnya daya hambat pada perlakuan iodip $10 \%$ (P0). Setiap perlakuan perasan daun binahong memiliki daya zona hamba pada setiap perlakuan ditunjukkan pada Gambar 1.

\section{Analisis uji hambat bakteri Escherichia coli}

Hasil pelaksanaan aquades menggunakan konsentrasi (P1) 60\%, (P2) 80\%, (P3)100\%, dan (P0) iodip $10 \%$ sebagai pembanding, terhadap bakteri Eschreichia coli menunjukkan hasil terbentuknya zona bening. Hasil pengukuran diameter zona hambat dapat dilihat pada Tabel 3.
Tabel 3. Analisis zona hambat bakteri Escherichia coli

\begin{tabular}{lll}
\hline Perlakuan & $\begin{array}{c}\text { Diameter } \\
\text { Zona } \\
\text { Hambat } \\
(\mathrm{mm})\end{array}$ & $\begin{array}{c}\text { Kategori } \\
\text { Respon }\end{array}$ \\
\hline P0 (iodip) & $8,20 \pm 4,24^{\mathrm{b}}$ & Kuat \\
P1 (60\%) & $3,55 \pm 1,54^{\mathrm{a}}$ & Sedang \\
P2 (80\%) & $4,09 \pm 2,07^{\mathrm{a}}$ & Sedang \\
P3 (100\%) & $9,15 \pm 4,57^{\mathrm{b}}$ & Kuat \\
\hline Keterangan: & $\begin{array}{l}\text { Superskrip } \\
\text { perbedaan } \\
\end{array}$ & merupakan \\
& antar \\
\end{tabular}

Hasil uji hambat terhadap bakteri Eschericia coli dengan adanya zonabening yang terbentuk, menurut Pan et al. (2009) bahwa zona hambat yang memiliki diameter 0-3 $\mathrm{mm}$ berkategori lemah, 3-6 $\mathrm{mm}$ untuk kategori sedang, dan >6 mm untuk kategori kuat, sehingga pada perlakuan perasan daun binahong konsentrasi $60 \%$ (P1) dan $80 \%$ (P2) hanya dapat dikategorikan berdaya hambat lemah sedangkan pada konsentrasi perasan daun binahong $100 \% \quad$ (P3) dapat dikategorikan berdaya hambat kuat seperti halnya pada perlakuan 
menggunakan iodip 10\% (P0). Namun, berdasarkan TaBe ${ }^{4} 3^{4}$ tersebut diketahui bahwa daya hambat bakteri Escherichia coli dengan perlakuan perasan daun binahong konsembrasis $4^{\mathrm{a}}$ $100 \%$ (P3) memiliki hasil yang tidak berbeda nyata terhadap perlakuan iodip (P0) sebagai pembanding. Sedangkan pada bakteri Staphylococcus aureus perlakuan dengan perasan daun binahong konsentrasi $100 \%$ (P3) memiliki hasil yang sangat berbeda n,nyat $y_{7}^{\mathrm{b}}$ dengan perlakuan iodip (P0). Hal ini disebabkan respon bakteri terhadap zat antibakteri memiliki perbedaan pada tiap-tiap ${ }^{4,0} 7^{\mathrm{a}^{\mathrm{j}}}$ jenisnya. Diperkuat oleh Jawetz et al. (1995) bahwa jenis bakteri gram positif akan lebih merespon adanya zat antibakteri daripada jenis bakteri gram negatif.

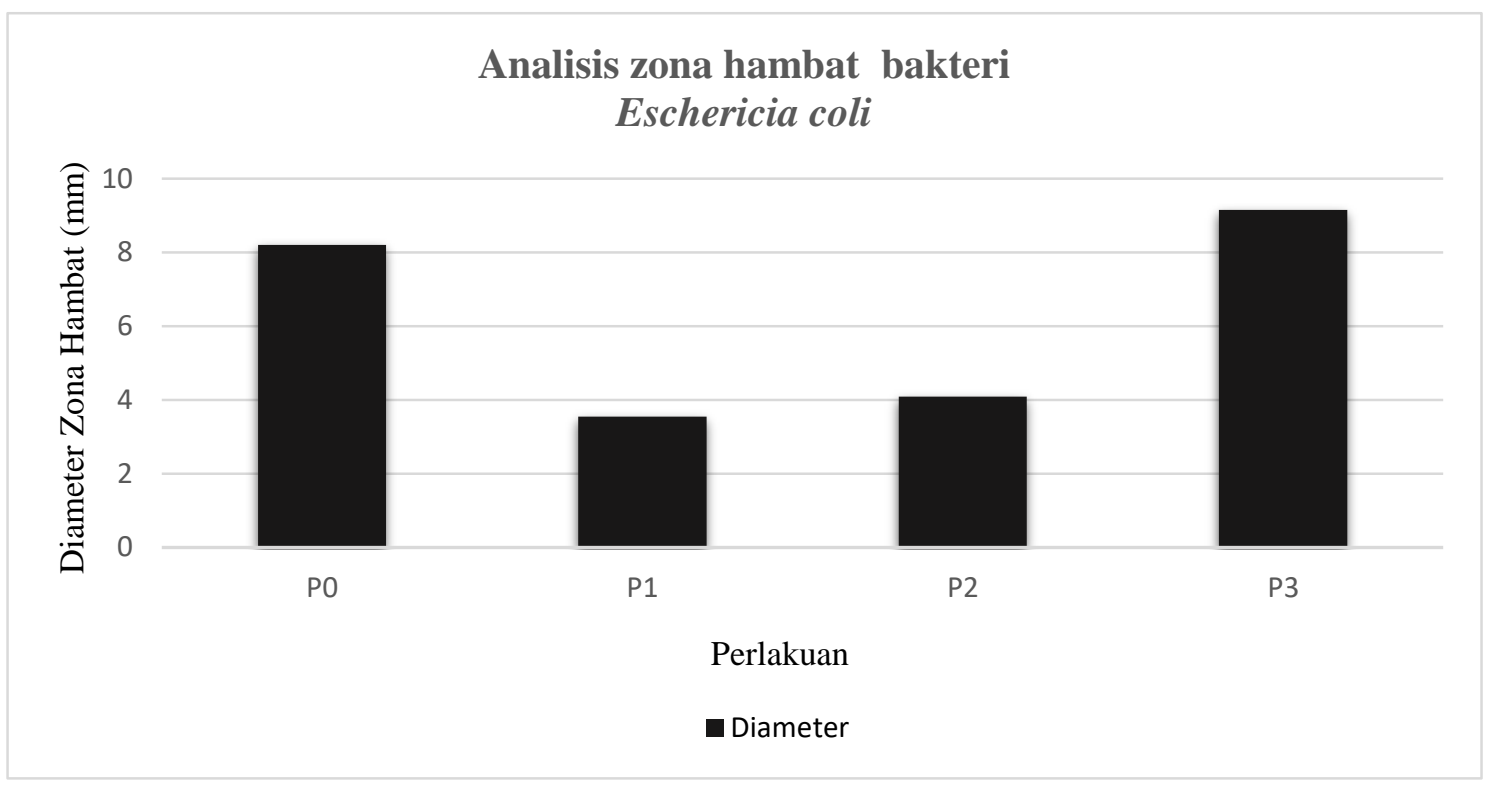

Gambar 2. Rataan diameter zona hambat perasan daun binahong dan iodip pada bakteri Escherichia coli 
Bakteri gram negatif memiliki dinding sel yang lebih kompleks daripada gram positif, struktur dinding sel bakteri gram negatif memiliki susunan berlapis diantaranya lipoprotein, lipopolisakarida, dan peptidoglikan.

Abrar

dkk.

menambahkan bahwa Escherichia coli juga mempunyai hemaglutinin namun tidak tersusun dari protein seperti halnya pada Staphylococcus aureus, fakta ini semakin memperkuat bahwa dinding sel Escherichia coli semakin sulit ditembus oleh zat antibakteri. Zat aktif yang terkandung dalam perasan daun binahong seperti flavanoid dan saponin yang memiliki sasaran utama melisiskan protein akan mengalami kesulitan dalam bekerja. Hal ini akan mengakibatkan kemampuan daya hambat perasan daun binahong pada bakteri Escherichia coli tidak sebesar pada bakteri Staphylococcus aureus. Grafik zona hambat perasan daun binahong terhadap bakteri Escherichia coli dapat dilihat pada Gambar 2.

\section{Perlakuan Terbaik}

Perlakuan terbaik digunakan sebagai acuan pada perlakuan mana yang menunjukkan hasil terbaik, yaitu konsentrasi perasan daun binahong yang dapat menghambat pertumbuhan bakteri Staphyococcus aureus dan Escherichia coli. terdapat pada perlakuan konsentrasi $100 \%$ (P3) dengan rataan daya hambat sebesar $(9,72 \pm 4,36) \mathrm{mm}$, sedangkan pada bakteri Escherichia coli terdapat pada perlakuan konsentrasi $100 \%$ (P3) dengan rataan daya hambat sebesar $(9,15 \pm 4,57) \mathrm{mm}$. Menurut kategori zona hambat, konsentrasi perasan daun binahong $100 \% \quad(\mathrm{P} 3)$ memiliki nilai daya hambat yang tergolong kuat seperti halnya pada nilai daya hambat yang dihasilkan iodip 10\% (P0). Perasan daun binahong konsentrasi
$100 \%$ juga terbukti dapat mengungguli besarnya daya hambat yang dihasilkan perlakuan kontrol iodip $10 \%$ (P0) sekaligus memiliki nilai daya hambat terbesar terhadap pertumbuhan bakteri Staphyococcus aureus maupun Escherichia coli. Berdasarkan perbandingan hasil penelitian dengan literatur terkait maka dapat disimpulkan bahwa potensi antibacterial pada sampel bakteri Staphylococcus aureus dan Escherichia coli adalah perasan daun binahong dengan konsentrasi 100\%.

\section{Upaya pemanfaatan perasan daun binahong}

Perasan daun binahong pada penilitian ini menggunakan bahan tunggal yaitu daun binahong yang diambil maksimal 10 urutan teratas atau tiga perempat dari pohon, tidak terlalu muda dan tidak terlalu tua. Daun dewasa (tidak terlalu tua) pertumbuhan jaringannya telah maksimal, dan daun yang sangat muda pada umumnya masih mengalami proses pertumbuhan dan perkembangan. trikoma yang merupakan tempat akumulasi zat bioaktif pada daun dewasa juga memiliki jumlah yang lebih banyak daripada daun berumur muda maupun sangat tua.

Perasan memiliki kelebihan dibanding metode lain seperti ekstraksi, yaitu pada proses pembuatannya yang lebih sederhana dan cepat. Perasan juga tidak membutuhkan peralatan rumit dan keterampilan khusus dalam pembuatannya, hal ini tentunya akan memberikan kemudahan kepada peternak apabila perasan daun binahong ini dapat diaplikasikan sebagai antibiotik alami pada pelaksanaan teat dipping. Metode perasan juga memiliki kekurangan apabila dibandingkan dengan metode lain seperti ekstraksi. Menurut Rosyada dan Hesti (2013) proses ekstraksi menggunakan zat pelarut tertentu untuk menghilangan zat 
yang tidak diinginkan sehingga pada proses penggunaannya hanya terdapat zat yang diinginkan. Hal ini tentunya akan mempercepat proses reaksi karena hanya zat yang diinginkanlah yang masih ada dan langsung bekerja pada titik sasarannya. Metode perasan masih memiliki nilai daya hambat terhadap pertumbuhan bakteri walaupun tidak memanfaatkan pelarut tertentu untuk mengikat zat yang diinginkan dan mengeluarkan zat yang tidak diinginkan seperti halnya pada ekstrak. Tabel 2 dan 3 menunjukkan hasil bahwa perasan daun binahong dengan berbagai konsentrasi masih memiliki nilai daya hambat terhadap pertumbuhan bakteri dengan terbentuknya zona bening yang dapat diukur. Penelitian lain tentang pemanfaatan berbagai macam herbal yang digunakan sebagai zat antibakteri juga menunjukkan adanya aktivitas menghambat bakteri. Penelitian oleh Kameswari dkk. (2013) mengenai penggunaan perasan daun mengkudu juga menunjukkan aktivitas hambatan terhadap pertumbuhan bakteri, dibuktikan juga oleh Hikma (2015) bahwa perasan daun sirsak terbukti memiliki aktivitas sebagai antibakteri. Penelitian tentang perasan daun srikaya yang dilakukan oleh Yunikawati dkk. (2013) juga menunjukkan adanya aktivitas antibakteri, walaupun memiliki hasil yang tidak dapat mengungguli besarnya antibakteri kimia. Aktivitas antibakteri daun binahong juga dipengaruhi oleh adanya bakteri endofit yang terkandung yaitu bakteri yang hidup dalam jaringan tanaman inang tanpa menimbulkan gejala penyakit dimana juga berfungsi sebagai antibakteri, keterangan Desriani dkk. (2014) menyebutkan terdapat sekitar 37 isolat murni dari binahong yang menghasilkan produk metabolit sekunder dan bersifat antibakteri terbukti dengan terbentuknya zona hambat. Proses ektraksi yang menggunakan pelarut kimia tertentu dikhawatirkan dapat ikut menghilangkan bakteri endofit ini sehingga dapat mempengaruhi khasiat dari daun binahong.

Perasan memiliki nilai ekonomis apabila dibanding dengan metode lain seperti ekstraksi. Rosyada dan Hesti (2013) menyatakan pada proses ekstraksi diperlukan zat pelarut yang tepat pada tiap zat yang diinginkan, alat tertentu dan biaya yang cukup mahal. Faktor tersebut tentunya akan memberatkan peternak di lapang apabila harus dilakukan ekstraksi pada daun binahong sebelum dimanfaatkan sebagai zat antibakteri. Proses ekstraksi juga akan menguras waktu dengan rumitnya proses pengerjaan, selain itu dibutuhkan proses penyuluhan untuk memberikan ilmu tentang pelaksanaan ekstraksi kepada peternak. Sehingga diharapkan dengan perasan daun binahong dalam segala keunggulannya tersebut dapat digunakan sebagai antibiotik alami pengganti antibiotik sintetis pada proses teat dipping sapi perah guna mencegah terjangkit penyakit mastitis.

\section{KESIMPULAN}

Dari hasil penelitian ini dapat di simpulkan bahwa

1. Perasan daun binahong (Anredera cordifolia (Ten.) Steenis) dapat dimanfaatkan sebagai alternatif zat antibakteri herbal dalam pelaksanaan pencelupan puting pada kasus mastitis yang disebabkan oleh Staphylococcus aureus dan Escherichia coli.

2. Perasan daun binahong (Anredera cordifolia (Ten.) Steenis) dengan konsentrasi $100 \%$ (tanpa campuran) memiliki kemampuan menghambat bakteri Staphylococcus aureus dan Escherichia coli lebih baik dibanding 
dengan iodip $10 \%$ sekaligus memiliki nilai daya hambat dengan kategori kuat $(>6 \mathrm{~mm})$ dan merupakan perlakuan terbaik.

3. Perlu dilakukan penelitian lebih lanjut tentang kandungan zat aktif dalam daun binahong dari berbagai metode ekstraksi.

4. Penelitian ini perlu diuji cobakan di lapang guna mengetahui efek penggunaan perasan daun binahong $100 \%$ secara in-vivo. Sehingga diharapkan perasan daun binahong dapat dijadikan zat antibakteri alami pada proses teat dipping.

\section{DAFTAR PUSTAKA}

Abrar, M., I W. T. Wibawan, B. P. Priosoeryanto, M. Soedarwanto, dan F. H. Pasaribu, 2012. Isolasi dan Karakterisasi Hemaglutinin Staphylococcus aureus Penyebab Mastitis Subklinis pada Sapi Perah. Jurnal Kedokteran Hewan, 6 (1): 16-21.

Abrar, M., I W. T. Wibawan, B. P. Priosoeryanto, M. Soedarwanto, dan F. H. Pasaribu. 2013. Peranan Hemaglutinin Staphylococcus aureus dalam Proses Adhesi pada Sel Epitel Ambing Sapi Perah. Jurnal Kedokteran Hewan, 7 (1): 43-46.

Astuti, S.M. 2012. Skrining Fitokimia dan Uji Aktifitas Antibiotika Ekstrak Etanol Daun, Batang, Bunga dan Umbi Tanaman Binahong (Anredera cordifolia (Ten) Steenis). Artikel Ilmiah. Fakulti Kejuteraan Kimia dan Sumber Asli (Bioproses). Universiti Malaysia Pahang. Malaysia.

Darsana, I. G. O., I. N. K. Besung dan H. Mahatmi. 2012. Potensi Daun Binahong (Anredera Cordifolia (Tenore) Steenis) dalam Menghambat Pertumbuhan
Bakteri Escherichia Coli secara In Vitro. Indonesia Medicus Veterinus, 1 (3): 337-351.

Darsono F. L dan S. D. Artemisia. 2003. Aktivitas Antimikroba Ekstrak Daun Jambu Biji dari Beberapa Kultivar terhadap Staphylococcus aureus ATCC 25923 dengan "Hole-Plate Diffusion Method". Berk. Penel. Jurnal Hayati, 9 (1): 49-51.

Desriani, U. M. Safira, M. Bintang, A. Rivai, P. Lisdiyanti. 2014. Isolasi dan Karakterisasi Bakteri Endofit dari Tanaman Binahong dan Katepeng China. Jurnal Kesehatan Andalas, 3 (2): 89-93.

Hikma, N., W. D. Uno, dan A. Abdul. 2015. Pengaruh Perasan Daun Sirsak (Annona Muricata L.) Terhadap Pertumbuhan Bakteri Escherichia Coli. Jurnal Fakultas Matematika dan Ilmu Pengetahuan Alam Universitas Negeri Gorontalo.

Jawetz, E., J. L. Melnick., E. A. Adelberg., G. F. Brooks., J. S. Butel., dan L. N. Ornston. 1995. Mikrobiologi Kedokteran. Jakarta : Penerbit Buku Kedokteran EGC.

Kameswari, M. S., I N. K. Besung, H. Mahatmi. 2013. Perasan Daun Mengkudu(Morinda Citrifolia) Menghambat Pertumbuhan Bakteri Escherichia Coli Secara In Vitro. Indonesia Medicus Veterinus, 2 (3): 322- 330.

Makalalag, I. W., A. Wullur, dan W. Wiyono. 2013. Uji Ekstrak Daun Binahong (Anredera cordifolia Steen.) Terhadap Kadar Gula Darah pada Tikus Putih Jantan Galur Wistar ( Rattus norvegicus) yang Diinduksi Sukrosa. Jurnal Ilmiah Farmasi, 2 (2): 28-35. 
Pan, X., F. Chen, T. Wu, H. Tang, and Z. Zhao. 2009. The acid, Bile Tolerance and Antimicrobial property of Lactobacillus acidophilus NIT. J. Food Control, 20 : 598-602.

Poeloengan, M. 2009. Pengaruh Minyak Atsiri Serai (Andropogon citratus $D C$.) terhadap Bakteri yang diisolasi dari Sapi Mastitis Subklinis. Berita Biologi, 9 (6): 715-719.

Prawira, M. Y., Sarwiyono, dan P. Surjowardojo. 2013. Daya Hambat Daun Dekok Daun Kersen (Muntingia calabura L.) terhadap Pertumbuhan Bakteri Staphylococcus aureus Penyebab Penyakit Mastitis pada Sapi Perah. Fakultas Peternakan Universitas Brawijaya. Malang.

Rosyada, S. M., H. Muwarni. 2013. Perbedaan Pengaruh antara Ekstrak dan Rebusan Daun Salam (Eugina polyntha) dalam Pencegahan Peningkatan Kadar Kolesterol Total pada Tikus Sprague Dawley. Artikel Penelitian Fakultas Kedokteran Universitas Diponegoro.

Setiawan, J.. P. Surjowardojo, E. Setyowati. 2007. Ekstrak Kloroform Daun Kersen (Muntingia calabura L.) sebagai Antibakteri Penghambat Pertumbuhan Bakteri Staphylococcus Aureus Penyebab Mastitis Subklinis pada Sapi Perah. Fakultas Peternakan UB.

Sugiri, Y. D. dan A. Anri. 2010. Prevalensi Patogen Penyebab Mastitis Subklinis (Staphylococcus aureus dan Streptococcus agalactiae) dan Patogen Penyebab Mastitis Subklinis lainnya pada Peternak Skala Kecil dan Menengah di
Beberapa Sentra Peternakan Sapi Perah di Pulau Jawa. BP3HK Lembang.

Yunikawati, M. P. A., I N. K. Besung, dan H. Besung. 2013. Efektifitas Perasan Daun Srikaya Terhadap DayaHambat Pertumbuhan Escherichia coli. Indonesia Medicus Veterinus, 2 (2): 170-179.

Zahara, N., A. Muhammad, dan P. Fifi. 2013. Uji Kemampuan Ekstrak Daun Beberapa Jenis Sirih (Piper sp.) untuk Mengendalikan Jamur Pathogen Tular Benih Kacang Tanah dan Pengaruhnya terhadap Daya Kecambah Benih. Universitas Riau. Riau. 